\title{
Tetragenococcus koreensis sp. nov., a novel rhamnolipid-producing bacterium
}

\author{
Correspondence \\ Sung-Taik Lee \\ e_stlee@kaist.ac.kr
}

\author{
Myungjin Lee, ${ }^{1,2}$ Myung Kyum Kim, ${ }^{2}$ Marc Vancanneyt, ${ }^{3}$ Jean Swings, ${ }^{3}$ \\ Seong-Hye Kim, ${ }^{2}$ Myung Suk Kang ${ }^{2}$ and Sung-Taik Lee ${ }^{2}$ \\ ${ }^{1}$ NeoPharm Co., Ltd, BVC-307, KRIBB, 52 Oeun-dong, Yuseong-gu, Daejeon 305-333, \\ Republic of Korea \\ ${ }^{2}$ Environmental and Molecular Microbiology Laboratory, Department of Biological Sciences, \\ Korea Advanced Institute of Science and Technology (KAIST), 373-1 Guseong-dong, \\ Yuseong-gu, Daejeon 305-701, Republic of Korea \\ ${ }^{3}$ BCCM/LMG Bacteria Collection, Laboratory of Microbiology, Faculty of Sciences, Ghent \\ University, K. L. Ledeganckstraat 35, B-9000 Ghent, Belgium
}

A Gram-positive, non-motile, non-spore-forming coccus (strain $\mathrm{JS}^{\top}$ ) was isolated from kimchi (a traditional Korean food) and investigated using a polyphasic taxonomic approach. The 16S rRNA gene sequence similarity between strain $\mathrm{JS}^{\top}$ and its closest relative, Tetragenococcus halophilus IAM $1676^{\top}$, was $98 \cdot 1 \%$. The level of DNA-DNA relatedness between the two strains was $9 \cdot 7 \%$. Strain JS ${ }^{\top}$ had a DNA G $+C$ content of $38 \cdot 3 \%$ and a cellular fatty acid profile containing 16:0,18:1 and cyclo fatty acids. Phylogenetic data and genomic and phenotypic features demonstrated that strain $\mathrm{JS}^{\top}$ represents a novel species, for which the name Tetragenococcus koreensis sp. nov. is proposed. The type strain is $\mathrm{JS}^{\top}\left(=\mathrm{KCTC} 3924^{\top}=\mathrm{DSM}\right.$ $16501^{\top}=$ LMG $22864^{\top}$ ).
The genus Tetragenococcus is classified within the family 'Enterococcaceae', which belongs to the order 'Lactobacillales' in the class 'Bacilli' (Garrity \& Holt, 2001). The genus was created by Collins et al. (1990) after reclassification of the halophilic lactic acid bacterium [Pediococcus] halophilus as Tetragenococcus halophilus. At present, the genus comprises three species: T. halophilus, Tetragenococcus muriaticus (Satomi et al., 1997) and Tetragenococcus solitarius (Ennahar \& Cai, 2005).

Kimchi is a common food in Korea. It is prepared with various kinds of vegetables, spices and other ingredients, and becomes palatable through ageing under anaerobic conditions. Kimchi fermentation is initiated by various micro-organisms present in the raw materials, but is gradually dominated by lactic acid bacteria.

Strain JS $^{\mathrm{T}}$ was isolated from a traditional Korean food, kimchi, by direct plating on glucose yeast peptone (GYP)/ sodium acetate/mineral salts agar at $\mathrm{pH} 7 \cdot 0$ (medium 243; BCCM). After 7 days incubation on GYP/sodium acetate/ mineral salts agar, colonies were smooth, low convex, circular, opaque, matt and white in colour. Strain $\mathrm{JS}^{\mathrm{T}}$ grew at

The GenBank/EMBL/DDBJ accession number for the 16S rRNA gene sequence of strain $\mathrm{JS}^{\top}$ is AY690334.

A scanning electron micrograph of cells of strain $\mathrm{JS}^{\top}$ is available as supplementary material in IJSEM Online.
$15-30{ }^{\circ} \mathrm{C}$ but not at, or above, $4{ }^{\circ} \mathrm{C}$ or at temperatures above $42^{\circ} \mathrm{C}$. The strain grew optimally at $\mathrm{pH} 9$. Optimal growth was obtained in 2-5\% (w/v) NaCl. Strain $\mathrm{JS}^{\mathrm{T}}$ did not grow under aerobic conditions on R2A agar (Difco), nutrient agar, MacConkey agar (Difco) or trypticase soy agar (Difco) at $30^{\circ} \mathrm{C}$. For maintenance of the culture and further analyses, strain JS ${ }^{\mathrm{T}}$ was grown on MRS agar (Difco) at $30^{\circ} \mathrm{C}$, unless specified otherwise.

Cell morphology and motility were observed under a Nikon Optiphot 111675 light microscope $(1000 \times$ magnification). Cell morphology was also examined by using scanning electron microscopy. The procedures used for sample fixation and preparation were as described by Chung \& Hancock (2000), with some modifications. Cells were non-spore-forming, non-motile cocci occurring singly or in pairs. The cell diameter was less than $1 \mu \mathrm{m}$ (see the Supplementary Figure in IJSEM Online) on GYP/sodium acetate/mineral salts agar. The Gram reaction, determined by the non-staining method described by Buck (1982), was positive. Oxidase activity was tested using the oxidation of $1 \% p$-aminodimethylaniline oxalate. Catalase activity was determined using bubble production with $3 \%(\mathrm{v} / \mathrm{v})$ hydrogen peroxide solution. Strain $\mathrm{JS}^{\mathrm{T}}$ showed no catalase or oxidase activities.

For 16S rRNA gene sequencing, cell biomass was obtained from cultures grown in MRS broth (Difco) on a horizontal 
shaker (150 r.p.m.) at $30^{\circ} \mathrm{C}$. The culture was checked for purity using a light microscope prior to harvesting by centrifugation. Chromosomal DNA was extracted and purified using the DNeasy Tissue Kit (Qiagen). The 16S rRNA gene was PCR-amplified and analysed as described by Yoon et al. (1998). Complete 16S rRNA gene sequences were compiled after sequencing using SeqMan software (DNASTAR), and 16S rRNA gene sequences of the test strains were edited using the BioEdit program (Hall, 1999) and aligned using CLUSTAL_X (Thompson et al., 1997). The phylogenetic tree was constructed by using the neighbourjoining method (Saitou \& Nei, 1987) in MEGA version 2.1 (Kumar et al., 2001).

The almost-complete sequence determined for the $16 \mathrm{~S}$ rRNA gene of strain JS ${ }^{\mathrm{T}}$ was a continuous stretch of $1492 \mathrm{nt}$ and there were no ambiguous bases. Analysis of 16S rRNA gene sequence similarities showed that strain JS ${ }^{\mathrm{T}}$ was most closely related to $T$. halophilus IAM $1676^{\mathrm{T}}(97 \cdot 8 \%), T$. solitarius DSM $5634^{\mathrm{T}}(97 \cdot 2 \%)$ and T. muriaticus JCM $10006^{\mathrm{T}}(95 \cdot 9 \%)$. The neighbour-joining tree showed that strain $\mathrm{JS}^{\mathrm{T}}$ and the three Tetragenococcus species formed a coherent cluster (supported by a bootstrap resampling value of $100 \%$ ) that was adjacent to genus Melissococcus (Fig. 1). This tree topology of the genus Tetragenococcus was also found in the trees generated by the maximum-parsimony algorithms (Kimura two-parameter model; Kimura, 1983).

Acid production from carbohydrates was determined as described by Hugh \& Leifson (1953). The API 20NE, API $32 \mathrm{GN}$, API $50 \mathrm{CH}$ and API 20 Strep microtest systems were used according to the recommendations of the manufacturer (bioMérieux). Strain $\mathrm{JS}^{\mathrm{T}}$ did not reduce nitrate to nitrite or nitrogen gas. Strain JS ${ }^{\mathrm{T}}$ had $\beta$-glucosidase and $\beta$ galactosidase activity but protein was not hydrolysed. The differential phenotypic properties of strain $\mathrm{JS}^{\mathrm{T}}$ and other type strains of species in the genus Tetragenococcus are summarized in Table 1.
For fatty acid methyl ester analysis, cell mass for all strains was obtained after 7 days incubation at $30{ }^{\circ} \mathrm{C}$ on GYP/ sodium acetate/mineral salts agar. Fatty acid methyl esters were prepared, separated and identified using the Sherlock Microbial Identification System (MIS; MIDI) (Sasser, 1990). Strain $\mathrm{JS}^{\mathrm{T}}$ had a cellular fatty acid profile containing large amounts of saturated, unsaturated and cyclo fatty acids. The fatty acid profile (Table 2) of strain $\mathrm{JS}^{\mathrm{T}}$ comprised the dominant fatty acids $\mathrm{C}_{16: 0}(22 \cdot 43 \%), \mathrm{C}_{18: 1} \omega 7 c / \omega 9 t / \omega 12 t$ $(33 \cdot 8 \%)$ and $\mathrm{C}_{19: 0}$ cyclo $\omega 8 c(26 \cdot 8 \%)$. No significant differences in the fatty acid profiles were found between strain JS ${ }^{\mathrm{T}}$ and other species of the genus Tetragenococcus.

The peptidoglycan structure of the cell wall was determined as described by Schleifer (1985) and Schleifer \& Kandler (1972), with the modification that TLC on cellulose was used instead of paper chromatography. The total hydrolysate of the peptidoglycan contained the amino acids alanine and glutamic acid plus smaller amounts of lysine and aspartic acid. In addition, the peptide L-Lys-D-Asp was detected; it is stable under the conditions used for total hydrolysis $\left(100^{\circ} \mathrm{C}, 4 \mathrm{M} \mathrm{HCl}, 16 \mathrm{~h}\right)$. Partial hydrolysis $\left(100{ }^{\circ} \mathrm{C}, 4 \mathrm{M} \mathrm{HCl}, 45 \mathrm{~min}\right)$ resulted in the peptides L-AlaD-Glu and L-Lys-D-Ala. From these data it was concluded that strain $\mathrm{JS}^{\mathrm{T}}$ possessed peptidoglycan type A4 $\alpha$ L-Lys-DAsp (type A11.31 according to http://www.dsmz.de/species/ murein.htm).

For determination of the DNA G $+\mathrm{C}$ content, genomic DNA was extracted and purified as indicated above for $16 \mathrm{~S}$ rRNA gene sequence analysis, and was then enzymically degraded into nucleosides as described previously (Mesbah et al., 1989; Tamaoka \& Komagata, 1984). The genomic DNA G + C content of strain JS ${ }^{\mathrm{T}}$ was $38 \cdot 3 \mathrm{~mol} \%$, which is a little higher than those of the other three species of the genus.

For DNA-DNA hybridizations, DNA was extracted as

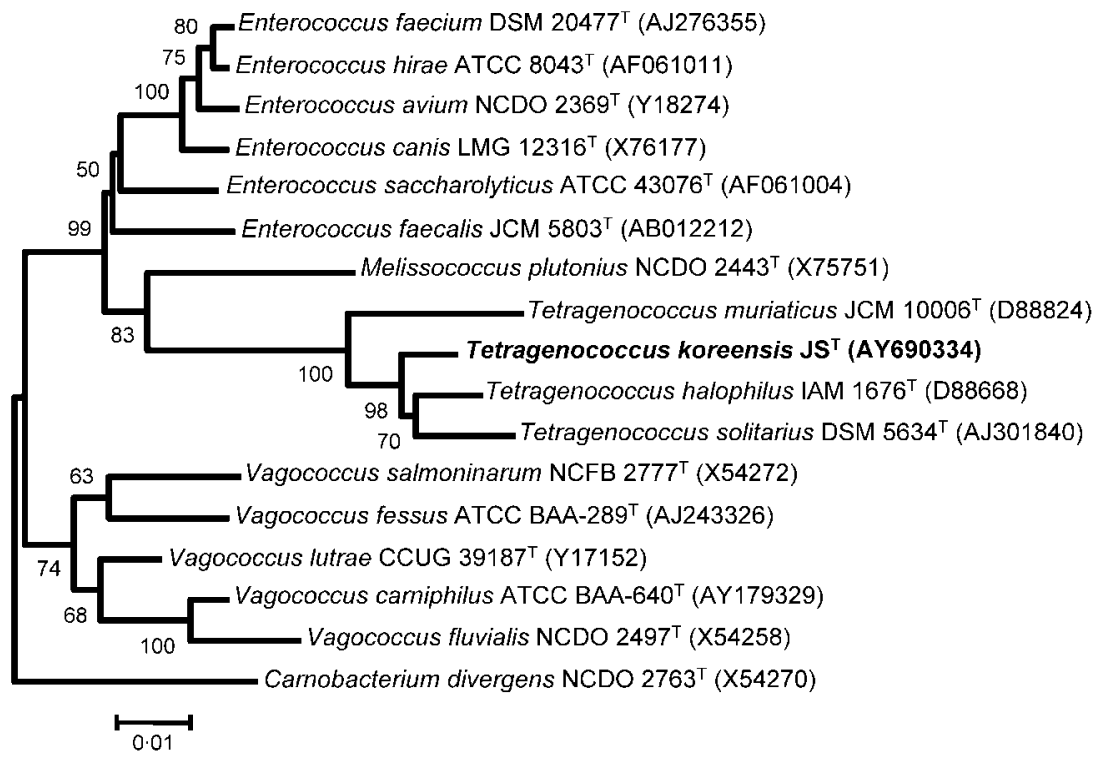

Fig. 1. Neighbour-joining tree, based on 16S rRNA gene sequences, showing the phylogenetic positions of strain $\mathrm{JS}^{\top}$ and other related taxa. Bootstrap values are expressed as percentages of 1000 replications. Bar, 0.01 substitution per nucleotide position. 
Table 1. Phenotypic characteristics that differentiate strain $\mathrm{JS}^{\top}$ from other members of the genus Tetragenococcus

Taxa: 1, T. halophilus IAM $1676^{\mathrm{T}}$; 2, T. muriaticus JCM $10006^{\mathrm{T}}$; 3, T. solitarius DSM $5634^{\mathrm{T}}$; 4, strain JS ${ }^{\mathrm{T}}$. All strains were Gram-positive cocci, non-motile, non-pigmented, catalase-negative and halophilic. All strains hydrolysed aesculin and had urease activity. All strains were positive for fermentation of $\mathrm{N}$-acetylglucosamine, D-glucose, D-fructose and salicin. All strains were negative for fermentation of L-fucose, 5 ketogluconate, lactose, D-lyxose, D-melibiose, methyl $\beta$-D-xyloside, D-raffinose, L-rhamnose, L-xylose, glycogen, starch, adonitol, L-arabitol, erythritol, glycerol, sorbitol and inulin. +, Positive reaction; -, negative reaction; w, weakly positive reaction; ND, no data.

\begin{tabular}{|c|c|c|c|c|}
\hline Characteristic & 1 & 2 & 3 & 4 \\
\hline Peptidoglycan & Lys-D-Asp & Lys-D-Asp & $\mathrm{ND}$ & Lys-D-Asp \\
\hline Growth at $45^{\circ} \mathrm{C}$ & - & - & + & - \\
\hline Optimum $\mathrm{NaCl}$ conc. $(\%, \mathrm{w} / \mathrm{v})$ & $5-10$ & $7-10$ & $\mathrm{ND}$ & $2-5$ \\
\hline Lactic acid production (homofermentative) & + & + & ND & + \\
\hline Growth on MRS & - & - & $\mathrm{ND}$ & + \\
\hline \multicolumn{5}{|l|}{ Fermentation of sugars } \\
\hline L-Arabinose & + & - & - & - \\
\hline D-Cellobiose & + & - & + & - \\
\hline Melezitose & - & - & + & + \\
\hline D-Ribose & + & + & - & + \\
\hline Sorbose & - & - & - & - \\
\hline D-Sucrose & + & - & + & + \\
\hline D-Tagatose & - & - & + & - \\
\hline D-Trehalose & + & - & + & + \\
\hline Turanose & - & - & + & + \\
\hline D-Xylose & + & - & - & + \\
\hline Methyl $\alpha$-D-glucoside & - & - & - & + \\
\hline Methyl $\alpha$-D-mannoside & - & - & - & + \\
\hline D-Arabitol & - & - & + & + \\
\hline
\end{tabular}

indicated above. Hybridizations were performed fluorometrically by the method of Ezaki et al. (1989), using photobiotin-labelled DNA probes and microdilution wells, with five replications for each sample. The highest and lowest values obtained for each sample were excluded; the remaining three values were used to calculate similarity values. The DNA relatedness values quoted are the means of these three values. Strain $\mathrm{JS}^{\mathrm{T}}$ exhibited low levels of DNA-DNA hybridization: $9 \cdot 7 \%$ with $T$. halophilus IAM $1676^{\mathrm{T}}, 61 \cdot 0 \%$ with T. solitarius DSM $5634^{\mathrm{T}}$ and $39 \cdot 0 \%$ with T. muriaticus JCM $10006^{\mathrm{T}}$.

Lactic acid production was analysed by using HPLC (Acme
HPLC; Younglin Instrument Co.). The HPLC analysis was performed with an HPLC system (processor, pump model SP930D, UV detector model UV 730D, column oven, auto-sampler) from Younglin Instrument Co. This was equipped with an Aminex HPX-87H organic acid analysis column from Bio-Rad. A $20 \mu \mathrm{l}$ aliquot of the $10^{-3}$ dilution of strain $\mathrm{JS}^{\mathrm{T}}$ culture broth was injected; $0.0035 \mathrm{M}$ $\mathrm{H}_{2} \mathrm{SO}_{4}$ solution was used as eluent, at $30^{\circ} \mathrm{C}$ and at a flow rate of $0.7 \mathrm{ml} \mathrm{min}^{-1}$. The lactic acid in the culture broth was detected using a UV detector $(210 \mathrm{~nm}$ ) (Younglin Instrument Co.) and compared with a standard lactic acid from Aldrich, USA. Strain JS ${ }^{\mathrm{T}}$ produced lactic acid homofermentatively. 
Table 2. Cellular fatty acid profiles of strains $\mathrm{JS}^{\top}$ and other closely related species in the genus Tetragenococcus

Taxa: 1, T. halophilus IAM $1676^{\mathrm{T}} ; 2$, T. muriaticus JCM $10006^{\mathrm{T}} ; 3$, T. solitarius DSM $5634^{\mathrm{T}}$; 4, strain $\mathrm{JS}^{\mathrm{T}}$. For unsaturated fatty acids, the position of the double bond is located by counting from the methyl $(\omega)$ end of the carbon chain; cis and trans isomers are indicated by the suffixes $c$ and $t$, respectively.

\begin{tabular}{|lcccc|}
\hline Fatty acid & $\mathbf{1}$ & $\mathbf{2}$ & $\mathbf{3}$ & $\mathbf{4}$ \\
\hline Saturated fatty acids & & & & \\
$12: 0$ & - & $0 \cdot 9$ & $2 \cdot 7$ & - \\
$14: 0$ & $8 \cdot 8$ & $8 \cdot 0$ & $18 \cdot 5$ & $7 \cdot 4$ \\
$16: 0$ & $28 \cdot 9$ & $21 \cdot 9$ & $23 \cdot 3$ & $22 \cdot 4$ \\
$17: 0$ cyclo & $1 \cdot 5$ & - & $2 \cdot 8$ & - \\
$18: 0$ & - & $1 \cdot 1$ & $2 \cdot 7$ & - \\
$19: 0$ cyclo $\omega 8 c$ & $14 \cdot 6$ & $6 \cdot 3$ & $12 \cdot 0$ & $26 \cdot 8$ \\
$19: 0$ cyclo $\omega 10 c$ & - & - & $3 \cdot 7$ & - \\
Unsaturated fatty acids & & & & \\
$16: 1 \omega 7 c$ & $16 \cdot 1$ & $18 \cdot 9$ & $13 \cdot 4$ & $9 \cdot 6$ \\
$18: 1 \omega 7 c / 9 t / 12 t$ & $25 \cdot 4$ & $36 \cdot 6$ & $11 \cdot 9$ & $33 \cdot 8$ \\
$18: 1 \omega 9 c$ & $2 \cdot 1$ & $2 \cdot 0$ & $4 \cdot 0$ & - \\
$18: 2 \omega 6,9 c$ & - & $1 \cdot 3$ & $2 \cdot 8$ & - \\
Branched fatty acids & & & & \\
$15: 0$ iso $2-\mathrm{OH}$ & $2 \cdot 5$ & $2 \cdot 0$ & $2 \cdot 5$ & - \\
$16: 0$ 2-OH & - & $1 \cdot 0$ & - & - \\
\hline
\end{tabular}

For the rhamnolipid production assay, HPLC was carried out using a Waters Altantis $\mathrm{dC}_{18}$ reversed-phase column $(150 \times 3.9 \mathrm{~mm}, 5 \mu \mathrm{m})$. An aliquot $(20 \mu \mathrm{l})$ of the strain $\mathrm{JS}^{\mathrm{T}}$ culture broth was injected; $100 \%$ water was used as eluent at $30{ }^{\circ} \mathrm{C}$ with a flow rate of $0.6 \mathrm{ml} \mathrm{min}{ }^{-1}$. Products were detected using a UV detector $(204 \mathrm{~nm})$, then compared with a standard rhamnolipid biosurfactant from the Korea Research Institute of Bioscience and Biotechnology (Daejeon, Republic of Korea). The surface tension of the cell-free culture broth was determined with a Thermo Cahn tensiometer with the WinDCA32 software suite (Cahn Instruments) according to the De Nöuy ring method (Zajic \& Seffens, 1984). To estimate the emulsification activity, $5 \mathrm{ml} \mathrm{n}$-hexadecane was added to $5 \mathrm{ml}$ cellfree culture broth in graduated test tubes. These tubes were then vortexed for $2 \mathrm{~min}$ and allowed to stand at $30{ }^{\circ} \mathrm{C}$. The emulsion stability was measured after incubation for $24 \mathrm{~h}$. The emulsification index $\left(\mathrm{E}_{24} \%\right)$ was calculated by dividing the height of the emulsion layer by the total height of the mixture and multiplying the quotient by 100 . The use of biosurfactants generally results in foaming, a decrease in surface tension, and emulsification of hydrocarbon substrates. The growth of strain JS ${ }^{\mathrm{T}}$ on $2-5 \%$ (w/v) $\mathrm{NaCl}$ on GYP/sodium acetate/mineral salts agar for 7 days lowered the surface tension to $34 \cdot 9$ dyne $\mathrm{cm}^{-1}$, and the emulsifying activity was $61 \cdot 5 \%$. It has been reported that rhamnolipids were produced by Pseudomonas aeruginosa (Rahman et al., 2002) from various substrates, including industrial waste (Haba et al., 2000). They are as diverse, in terms of chemical structure and properties, as the producer micro-organisms (Kosaric, 1987). Biosurfactants are biodegradable, less toxic, less allergenic and therefore less detrimental to the environment.

The overall results of the present study allowed us to assign strain $J S^{\mathrm{T}}$ to a novel species, for which we propose the name Tetragenococcus koreensis sp. nov.

\section{Description of Tetragenococcus koreensis sp. nov.}

Tetragenococcus koreensis (ko.re.en'sis. N.L. masc. adj. koreensis pertaining to Korea, the origin of the sample of the traditional food, kimchi, from which the type strain was isolated).

Cells are non-motile, non-spore-forming cocci (approx. $1 \mu \mathrm{m}$ in length). Gram-positive, catalase-negative, oxidasenegative. Grows on trypticase soy agar at $30^{\circ} \mathrm{C}$ aerobically and in an anaerobic jar, but does not grow on R2A agar, nutrient agar or MacConkey agar at $30^{\circ} \mathrm{C}$ under either aerobic or anaerobic conditions. Fatty acid profile largely composed of $\mathrm{C}_{18: 1} \omega 7 c(33 \cdot 8 \%), \mathrm{C}_{19: 0}$ cyclo $\omega 8 c(26 \cdot 8 \%)$ and $\mathrm{C}_{16: 0}(22 \cdot 4 \%)$. Growth occurs at $15-30{ }^{\circ} \mathrm{C}$ on GYP/ sodium acetate/mineral salts agar but not at temperatures of $4{ }^{\circ} \mathrm{C}$ or above $37^{\circ} \mathrm{C}$. Optimum growth temperature is $30^{\circ} \mathrm{C}$. Optimal $\mathrm{pH}$ is $9 \cdot 0$. Growth occurs at $\mathrm{NaCl}$ concentrations in the range $0-8 \%(\mathrm{w} / \mathrm{v})$. The $\mathrm{NaCl}$ concentration for best growth is $2-5 \%(\mathrm{w} / \mathrm{v})$. Facultatively aerobic. Demonstrates homofermentative production of lactic acid. The peptidoglycan type is A $4 \alpha$ L-Lys-D-Asp. Nitrate is not reduced to nitrite or nitrogen gas. The $\mathrm{G}+\mathrm{C}$ content of the DNA is $38.3 \mathrm{~mol} \%$. $\beta$-Glucosidase- and $\beta$-galactosidasepositive, but protein is not hydrolysed. Characterized by the production of rhamnolipid biosurfactant.

The type strain is $\mathrm{JS}^{\mathrm{T}}\left(=\mathrm{KCTC} 3924^{\mathrm{T}}=\mathrm{DSM} 16501^{\mathrm{T}}=\right.$ LMG $22864^{\mathrm{T}}$ ). Isolated from the traditional Korean food kimchi in Daejeon, South Korea.

\section{Acknowledgements}

This work was supported by grants from the Ministry of the Environment of the Republic of Korea; these grants are gratefully acknowledged.

\section{References}

Buck, J. D. (1982). Nonstaining (KOH) method for determination of Gram reactions of marine bacteria. Appl Environ Microbiol 44, 992-993.

Chung, W. \& Hancock, R. E. W. (2000). Action of lysozyme and nisin mixtures against lactic acid bacteria. Int J Food Microbiol 60, 25-32.

Collins, M. D., Williams, A. M. \& Wallbanks, S. (1990). The phylogeny of Aerococcus and Pediococcus as determined by $16 \mathrm{~S}$ rRNA sequence analysis: description of Tetragenococcus gen. nov. FEMS Microbiol Lett 70, 255-262.

Ennahar, S. \& Cai, Y. (2005). Biochemical and genetic evidence for the transfer of Enterococcus solitarius Collins et al. 1989 to the genus 
Tetragenococcus as Tetragenococcus solitarius comb. nov. Int J Syst Evol Microbiol 55, 589-592.

Ezaki, T., Hashimoto, Y. \& Yabuuchi, E. (1989). Fluorometric deoxyribonucleic acid-deoxyribonucleic acid hybridization in microdilution wells as an alternative to membrane filter hybridization in which radioisotopes are used to determine genetic relatedness among bacterial strains. Int J Syst Bacteriol 39, 224-229.

Garrity, G. M. \& Holt, J. G. (2001). The road map to the Manual. In Bergey's Manual of Systematic Bacteriology, 2nd edn, vol. 1, pp. 119-166. Edited by G. M. Garrity, D. R. Boone \& R. W. Castenholz. New York: Springer.

Haba, E., Espuny, M. J., Busquets, M. \& Manresa, A. (2000). Screening and production of rhamnolipids by Pseudomonas aeruginosa 47T2 NCIB 40044 from waste frying oils. J Appl Microbiol 88, 379-387.

Hall, T. A. (1999). BioEdit: a user-friendly biological sequence alignment editor and analysis program for Windows 95/98/NT. Nucleic Acids Symp Ser 41, 95-98.

Hugh, R. \& Leifson, E. (1953). The taxonomic significance of fermentative versus oxidative metabolism of carbohydrates by various gram negative bacteria. J Bacteriol 66, 24-26.

Kimura, M. (1983). The Neutral Theory of Molecular Evolution. Cambridge: Cambridge University Press.

Kosaric, N. (1987). Integrated process for continuous rhamnolipid biosynthesis. Biosurfactants production, properties, applications. In Surfactant Science Series, vol. 48, pp. 157-173. New York: Marcel Dekker.

Kumar, S., Tamura, K., Jakobsen, I. B. \& Nei, M. (2001). MEGA2: molecular evolutionary genetics analysis software. Bioinformatics 17, 1244-1245.

Mesbah, M., Premachandran, U. \& Whitman, W. B. (1989). Precise measurement of the $\mathrm{G}+\mathrm{C}$ content of deoxyribonucleic acid by high-performance liquid chromatography. Int J Syst Bacteriol 39, 159-167.

Rahman, K. S. M., Rahman, T. J., McClean, S., Marchant, R. \& Banat, I. M. (2002). Rhamnolipid biosurfactant production by strains of Pseudomonas aeruginosa using low-cost raw materials. Biotechnol Prog 18, 1277-1281.

Saitou, N. \& Nei, M. (1987). The neighbor-joining method: a new method for reconstructing phylogenetic trees. Mol Biol Evol 4, 406-425.

Sasser, M. (1990). Identification of Bacteria by Gas Chromatography of Cellular Fatty Acids. MIDI Technical Note 101. Newark, DE: MIDI.

Satomi, M., Kimura, B., Mizoi, M., Sato, T. \& Fujii, T. (1997). Tetragenococcus muriaticus sp. nov., a new moderately halophilic lactic acid bacterium isolated from fermented squid liver sauce. Int J Syst Bacteriol 47, 832-836.

Schleifer, K. H. (1985). Analysis of the chemical composition and primary structure of murein. Methods Microbiol 18, 123-156.

Schleifer, K. H. \& Kandler, O. (1972). Peptidoglycan types of bacterial cell walls and their taxonomic implications. Bacteriol Rev 36, 407-477.

Tamaoka, J. \& Komagata, K. (1984). Determination of DNA base composition by reversed phase high-performance liquid chromatography. FEMS Microbiol Lett 25, 125-128.

Thompson, J. D., Gibson, T. J., Plewniak, F., Jeanmougin, F. \& Higgins, D. G. (1997). The CLUSTAL_X windows interface: flexible strategies for multiple sequence alignment aided by quality analysis tools. Nucleic Acids Res 25, 4876-4882.

Yoon, J.-H., Lee, S. T. \& Park, Y.-H. (1998). Inter- and intraspecific phylogenetic analysis of the genus Nocardioides and related taxa based on 16S rDNA sequences. Int J Syst Bacteriol 48, 187-194.

Zajic, J. \& Seffens, W. (1984). Biosurfactants. Crit Rev Biotechnol 12, 87-107. 